\title{
71. A Comparative analysis of role perceptions and expectations of medical doctors and interpreters in healthcare settings ${ }^{12}$
}

\section{Olcay ŞENER ERKIRTAY 3}

Şeyda KINCAL4

\begin{abstract}
APA: Şener Erkırtay, O.; Kıncal, Ş. (2021). A Comparative analysis of role perceptions and expectations of medical doctors and interpreters in healthcare settings. RumeliDE Dil ve Edebiyat Araştırmaları Dergisi, (23), 1100-1118. DOI: 10.29000/rumelide.950025.
\end{abstract}

\begin{abstract}
It is a fact that interpreters act as important language facilitators by bridging the gaps between the parties. Especially Cecilia Wadensjö's (1998) influential research on community interpreting presented a new perspective in which the interpreter started to be perceived as an active participant assuming different roles and having power during the interactions (Van de Mieeroop, 2012:1). Thus, various scholars started examining the interpreters as active participants. On the other hand, user expectations and perceptions are also among the key factors defining the role of the interpreter. With this purpose, this study attempts to explore, compare and contrast the role perceptions and expectations of medical doctors and healthcare interpreters in accordance with the expectancy norms and the professional norms, as part of an ongoing $\mathrm{PhD}$ thesis. The data analyzed in this paper were obtained from questionnaires submitted to 22 medical doctors working in private hospitals and clinics, and interviews conducted with 13 interpreters working in private hospitals in Turkey. Preliminary findings reveal that interpreters mostly meet the doctors' expectations in terms of role. However, there are also certain aspects that diverge from this finding. The comparative analysis that this study aims to undertake is hoped to provide an insight into the conflicting views on perceptions and expectations that shape the healthcare interpreter's role.
\end{abstract}

Keywords: Healthcare interpreting, role perceptions, users' expectations

\section{Hastane ortamlarında doktor ve çevirmenlerin rol algıları ve beklentilerine yönelik karşılaştırmalı bir analiz}

\section{$\ddot{\mathbf{O z}}$}

Çevirmenlerin taraflar arasında köprü kurarak anlaşmayı kolaylaştırdığı bir gerçektir. Cecilia Wadensjö’nün (1998) toplum çevirmenliği üzerine yaptığı araştırması, çevirmenlerin farklı roller üstlenerek görüşmeler sırasında önemli güce sahip olan aktif bir katılımcı olduğu görüşüyle yeni bir perspektif kazandırmıştır (Van de Mieeroop, 2012:1). Bu sebeple, birçok araştırmacı çevirmenleri aktif bir katılımcı olarak incelemeye başlamıştır. Diğer yandan kullanıcı beklentileri ve algıları da

This paper is based on an ongoing Ph. D thesis authored by Olcay Şener Erkırtay under the supervision of Asst. Prof. Dr. Şeyda Kıncal and Prof. Dr. Ebru Diriker at Dokuz Eylül University, Institute of Social Sciences, Translation Studies Ph. D Programme

2 This paper is an extended and revised version of oral presentation done at the International Aegean Symposium on Social Sciences \& Humanities III on March 12-13, 2021/ Izmir, Turkey

Arş. Gör., Dokuz Eylül Üniversitesi, Edebiyat Fakültesi, Mütercim ve Tercümanlık Bölümü (İzmir, Türkiye), senerr.olcay@gmail.com, ORCID ID: 0000-0002-5971-2585 [Arastırma makalesi, Makale kayıt tarihi: 08.04.2021kabul tarihi: 20.06.2021; DOI: 10.29000/rumelide.950025], ETİK: Dokuz Eylül Üniversitesi Hukuk Müşavirliğ̈i, 29.09.2020, 87347630/42104268/4150.

4 Dr. Öğr. Üyesi, Dokuz Eylül Üniversitesi, Edebiyat Fakültesi, Mütercim ve Tercümanlık Bölümü (İzmir, Türkiye), eraslan.seyda@gmail.com, ORCID ID: oooo-0003-4713-1537

Adres $\mid$ Address

RumeliDE Dil ve Edebiyat Araşttrmalar Dergisi $\quad$ RumeliDE Journal of Language and Literature Studies Osmanağa Mahallesi, Mürver Çiçeği Sokak, No:14/8 Osmanağa Mahallesi, Mürver Çiçeği Sokak, No:14/8

Kadıköy - İSTANBUL / TÜRKIYE 34714 Kadıköy - ISTANBUL / TURKEY 34714 e-posta: editor@rum tel: +90 $5057958124,+902167730616$

e-mail: editor@rumelide.com

phone: +90 505 7958124, +90 2167730616 
çevirmenin rolünü belirleyen önemli faktörlerdir. Bu amaçla, devam etmekte olan bir doktora araştırmasının bir bölümünü oluşturan bu çalışma, beklenti normları ve profesyonel normlar çerçevesinde, doktorların ve çevirmenlerin rol algılarını ve beklentilerini ortaya koymayı ve karşılaştırmalı incelemeyi hedeflemektedir. Veriler özel hastanelerde çalışan 22 doktora iletilen anketler ve aynı şekilde özel hastanelerde çalsşan 13 hastane çevirmeniyle gerçekleştirilen röportajlardan elde edilmiştir. Ön bulgular, çevirmenlerin rol anlamında çoğunlukla doktorların beklentilerini karşıladığını ortaya koymaktadır. Fakat, ayrıldıkları noktalar da bulunmaktadır. Bu çalışmanın hedeflediği karşılaştırmalı analiz, hastane çevirmenin rolünü etkileyen algı ve beklentiler üzerine bir bakış açısı sunmayı amaçlamaktadır.

Anahtar kelimeler: Hastane çevirmenliği, rol algıları, kullanıcı beklentileri

\section{Introduction}

The increased mobility of people from one country to another has paved the way for an increased need for community interpreters who could enable smooth communication between the parties in a variety of public service settings, including healthcare settings. Thus, the research into this field "cannot be overemphasized" (Bolden, 2000: 387). Turkey also harbors a large number of tourists who come to our country either for taking a vacation or for an operation within the scope of health tourism. Therefore, it might not be wrong to say that healthcare interpreters are heavily in demand at hospitals during these encounters. The interpreter's role, on the other hand, is influenced by a number of factors, including the expectations and perceptions of users. However, there is still an uncertainty regarding what kind of qualifications the users expect the interpreters to have or to what extent the users are aware of the significance of the profession and the role of the interpreter. Thus, this study aims at eliciting the users', namely, the medical doctors' role perceptions and expectations, and analyzing the data obtained from the users comparatively with the data gathered from the healthcare interpreters, which constitute preliminary data of a broader ongoing study.

\section{Literature review}

Tourism is an important sector which has a direct impact on the country's economy. Especially health tourism, which can be considered as a field under the umbrella term of "tourism", has larger effect on the country's economy in comparison to tourism in general (Aslanova, 2013: 131). Turkey can also be counted among the top destinations attracting attention of foreign patients for medical treatments. Thus, healthcare interpreters who are the mediating agents in providing communication between service provider and patient, are required and furthermore, academic research needs to be conducted in this field so as to analyze the role of the interpreters and the interpreting service in order to improve service quality and provide solutions to the problems, if any.

According to assertion of Mine Güven (2014), the first academic research conducted on healthcare interpreting in Turkey belongs to Jonathan Ross and İbrahim Dereboy (2009). In their research, which was carried out as a part of an EU-Grundtvig project called Training Intercultural and Bilingual Competencies in Health and Social Care (TRICC), Ross and Dereboy (2009) focused on ad hoc interpreting services in the Eastern/South Eastern Anatolia. Assuming that the language barrier can obstruct the communication between doctor and patient, they made suggestions in order to improve this problem, such as assigning bilingual doctors to the region, providing doctors with language training, raising awareness, and training interpreters, etc.

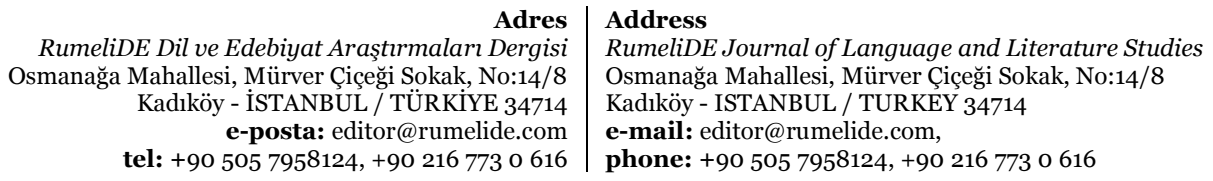


A Comparative analysis of role perceptions and expectations of medical doctors and interpreters in healthcare settings / O. Şener Erkırtay, Ş. Kıncal (pp. 1100-1118)

Mine Güven (2014), on the other hand, primarily focused on distance learning for medical interpreter training in Turkey and proposed two certificate programmes: "a three-year programme" for healthcare professionals and "a one-year programme" for prospective medical interpreters who have completed secondary education and could speak Turkish and a local/ethnic language at $\mathrm{C} 1$ or $\mathrm{C} 2$ level (Güven, 2014: 8-9). Another suggestion made by Güven is an in-service training which could be organized for training healthcare professionals in order to raise awareness regarding the significance of working with interpreters. Like Ross and Dereboy, Güven also attempted to contribute to improving quality of service and eliminating language barriers. In line with those objectives, they offered invaluable suggestions for enhancing the quality of service provided.

Following Ross' and Dereboy's (2009) as well as Güven's research (2014), the field has gained increasing attention among the scholars. Türkan Öztürk (2015), for instance, completed an MA thesis in which she pictured the current situation of healthcare interpreting services provided in Turkey from the interpreters' perspectives. With this purpose in mind, she conducted interviews with 20 interpreters from four different cities of Turkey and concluded that interpreters assume different roles in addition to the task of interpreting including the role of cultural mediator (Öztürk, 2015: 128).

A year later, Dilek Turan (2016) published a book titled "Interpreting in Healthcare Settings" (translated from its Turkish version 'Sağlık Hizmetlerinde Sözlü Çeviri') where she made suggestions to improve quality of service, including raising awareness of those who work with interpreters at various institutions regarding community interpreting as a profession, employing trained interpreters in community interpreting, as well as offering training programmes at the Translation and Interpreting departments of universities (Turan, 2016: 229).

Another MA thesis was completed by Olcay Şener in 2017. In addition to the interviews with healthcare interpreters working in private hospitals in Turkey, she also examined the data obtained from audio-recordings and participant observations from interpreter- mediated interactions in terms of ethical implications of the interpreter's decisions. 5

Duygu Duman (2018) is the first researcher who completed a Ph. D dissertation in this field. She focused on the healthcare interpreter's subjectivity experience before, during and after the interpreting process drawing on triangulation of data consisting of transcriptions of the interviews with 27 healthcare interpreters, research diaries and the document analysis conducted on national and international codes of ethics. She reveals that healthcare interpreters might adopt different approaches to the ethical principles stated in the international codes of ethics. Furthermore, subjective decisions of the interpreters, according to Duman (2018), might also shape their professional role.

One of the recent studies conducted in Turkey pertains to Burak Özsöz (2019) in which he investigated participatory dynamics in mediated three-party encounters in hair transplantation centers. He focused both on verbal and non-verbal data and analyzed the participants' gazes on non-verbal dimension, whereas he focused on question and answer pairs on verbal dimension. One of the conclusions he drew in his study is that the interpreter was observed to have answered the patient's questions himself/herself, thus, taking an authority which is supposed to be taken by the representative.

More recently, Filiz Şan and Rana Kahraman Duru (2020) published an article on healthcare interpreters' working conditions during COVID-19 pandemic through the questionnaires submitted to

Another MA thesis conducted on healthcare interpreting belong to Slla Saadet Toker (2019) and Bahar Katar (2019).

Adres $\mid$ Address

RumeliDE Dil ve Edebiyat Araşttrmalar Dergisi $\quad$ RumeliDE Journal of Language and Literature Studies

Osmanağa Mahallesi, Mürver Çiçeği Sokak, No:14/8 Osmanağa Mahallesi, Mürver Çiçeği Sokak, No:14/8

Kadıköy - ISTANBUL / TÜRKIYE 34714 Kadıköy - ISTANBUL / TURKEY 34714

e-posta: editor@rumelide.com

e-mail: editor@rumelide.com

tel: +90 505 7958124, +90 2167730616 phone: +90 505 7958124, +90 2167730616 
the interpreters. They handled the interpreters' conditions under four headings, namely, profile of the interpreters, general impact of the COVID-19 and the working conditions, the challenging personal and environmental factors for the interpreters, and improving the conditions for the interpreters and their general opinions. As a consequence, Şan and Kahraman Duru (2020) put forth the factors causing inefficiency in the working conditions of the interpreters, exemplifying that the interpreters cannot benefit from support packages under the status of healthcare workers. Thus, the working conditions should be revised taking into account hygiene of their work environment, waiting room, and waiting period during the pandemic and the risk they have for catching COVID-19 virus.

As for literature review on healthcare interpreting, it can be seen from the above-mentioned studies that invaluable contributions were made and continue to be made in the field so as to raise awareness and provide quality service in Turkey. This study intends to further contribute to the field by revealing the doctors' perceptions and expectations of the interpreter's role in healthcare settings, which is an important factor determining the role of the interpreter.

\section{Data collection methods}

With a view to finding answers to the abovementioned research objectives, both qualitative and quantitative data collection methods were applied to provide an in-depth comparative analysis of the interpreter's role. These data collection methods are comprised of semi-structured interviews with healthcare interpreters and questionnaires submitted to medical doctors. According to Hale and Napier (2013: 95), interviews include an in-depth discussion on a specific topic with the participants who represent the culture of their community under investigation and aim at "gaining an understanding into the experience of other people and the meaning they make of that experience". Thus, semi-structured interviews with open-ended questions were posed to the interpreters which enabled them to share their experience in detail.

In order to be able to conduct the research, the questionnaires were approved by the ethics committee of Dokuz Eylül University Rectorate. Furthermore, a consent form encompassing the scope and the objective of the research was sent to all interviewees through an e-mail because of the pandemic, and all of them gave consent through e-mails asserting that they read the consent form and confirmed it. The interviews were conducted online with all interpreters working in private hospitals in Istanbul, Ankara, and Izmir, and included a total of 27 questions. The answers of the interpreters were audiorecorded and transcribed afterwards.

In the same manner, questionnaires provide valuable data regarding facts, opinions, behaviors, attitudes, etc. of research participants (Saldanha and O'Brien, 2013: 152). One of its advantages is that it is less time consuming when compared to interviews. In return, they provide only an overview about the issues under investigation. However, in the present study, the findings obtained from interviews and questionnaires will be complementary to one another so as to benefit from both qualitative and quantitative methods and to remove the cons of each method. As far as the limited time that medical doctors have is concerned, questionnaire was an appropriate method to learn about their preferences and perceptions regarding role. A total of 22 doctors working at private hospitals and clinics in Ankara and Izmir participated in the study and filled out the questionnaires. There were 25 questions posed to the doctors including demographic information such as gender, age, foreign language levels, and role expectations and perceptions.

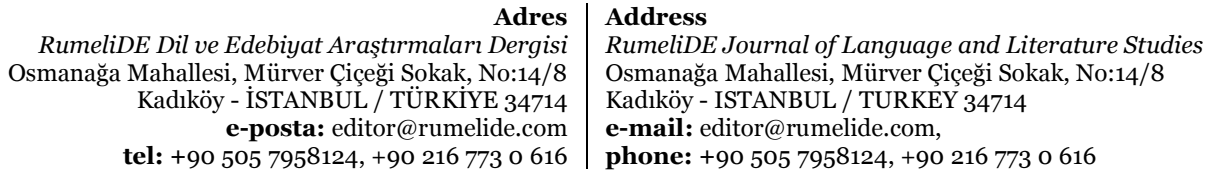

tel: $+905057958124,+902167730616$ 
A Comparative analysis of role perceptions and expectations of medical doctors and interpreters in healthcare settings / O. Şener Erkırtay, Ş. Kıncal (pp. 1100-1118)

\section{Translational norms in interpreting studies}

The comparative analysis of the data gathered from the participants will rely on the concept of norm. Toury (1995: 54) posits that translation is a norm-governed activity and subject to various types of sociocultural constraints on a varying degree, and postulates three major translational norms in descriptive translation studies which are initial norms, preliminary norms and operational norms (Toury, 1995: 55- 61). Chesterman (1997: 64), on the other hand, extends the approach of Toury's (1995) operational and initial norms to include product and process norms. Chesterman (1997: 64) especially elaborates on product norms, indicating that product norms are constituted by expectations of the target language readership which, in turn, constitute expectancy norms. These expectancy norms are composed of "user expectations" (Garzone, 2015) and determined by the receivers of the translation as to what the translation (of a given type) should be like (Chesterman, 2017: 174). Likewise, the users of interpreting also have expectations as to how interpreting should be performed and user's ideas about what a good interpretation should be like shape the interpreter's professional norms (Garzone, 2015: 283). Professional or process norms, on the other side, administer the translation process and "from the translator's point of view, these norms are subordinate to the expectancy norms, because they are themselves determined by the expectancy norms" (Chesterman, 1997: 67). If a translation is considered as conforming to the expectancy norms, then the translator of the text is accepted as being a professional (ibid: 67- 68). When the definition of the norm in translation studies is taken into account, it becomes visible that it could also be employed in interpreting studies since the interpreters also have to abide by the norms accepted and expected in a community, and they also have to provide interpretation service based on the expected professional norms (Koscialkowska-Okonska, 2011: 27).

The concept of norm was extended by Miriam Shlesinger to interpreting studies, specifically with regard to simultaneous interpreting. Following Shlesinger (1989), a number of scholars (Harris, 1990; Gile, 1999; Diriker, 2004) started to contemplate on the applicability of norms in interpreting studies. There are also scholars who have examined the concept of norm in simultaneous interpreting (Özkaya, 2015) and church interpreting (Balc1- Tison, 2016) in Turkey. Bearing in mind the objective of this study, the data obtained from the discourse of the doctors and the interpreters will be compared and analyzed in accordance with the expectancy norms and the professional norms.

\section{Analysis of questionnaires}

Similar questions were asked to both doctors and interpreters in order to comparatively analyze their answers. All the doctors were reached through personal contacts. 7 of the them are female, while the rest 15 doctors are male. Their ages range between 29 years and 75 years. When asked whether they could speak foreign languages, more than 90\% indicated that they speak English (see Figure 1). However, three doctors indicated that they could also speak other languages besides English. For instance, one could speak English and German, one could speak English and Swedish, while another one could speak English, Russian and Azerbaijani.

The most common spoken foreign language among the doctors involved in the study is English and when it comes to their level of English, it can be stated that a lot of doctors $(45,45 \%)$ are intermediate in English (see Figure 2).

\begin{tabular}{r|l} 
Adres & Address \\
RumeliDE Dil ve Edebiyat Araşttrmaları Dergisi & RumeliDE Journal of Language and Literature Studies \\
Osmanağa Mahallesi, Mürver Çiçeği Sokak, No:14/8 & Osmanağa Mahallesi, Mürver Çiçeği Sokak, No:14/8 \\
Kadıköy - İSTANBUL / TÜRKIYY 34714 & Kadıköy - ISTANBUL / TURKEY 34714 \\
e-posta: editor@rumelide.com & e-mail: editor@rumelide.com, \\
tel: +90 505 7958124, +90 2167730616 & phone: +90 505 7958124, +90 216773 o 616
\end{tabular}




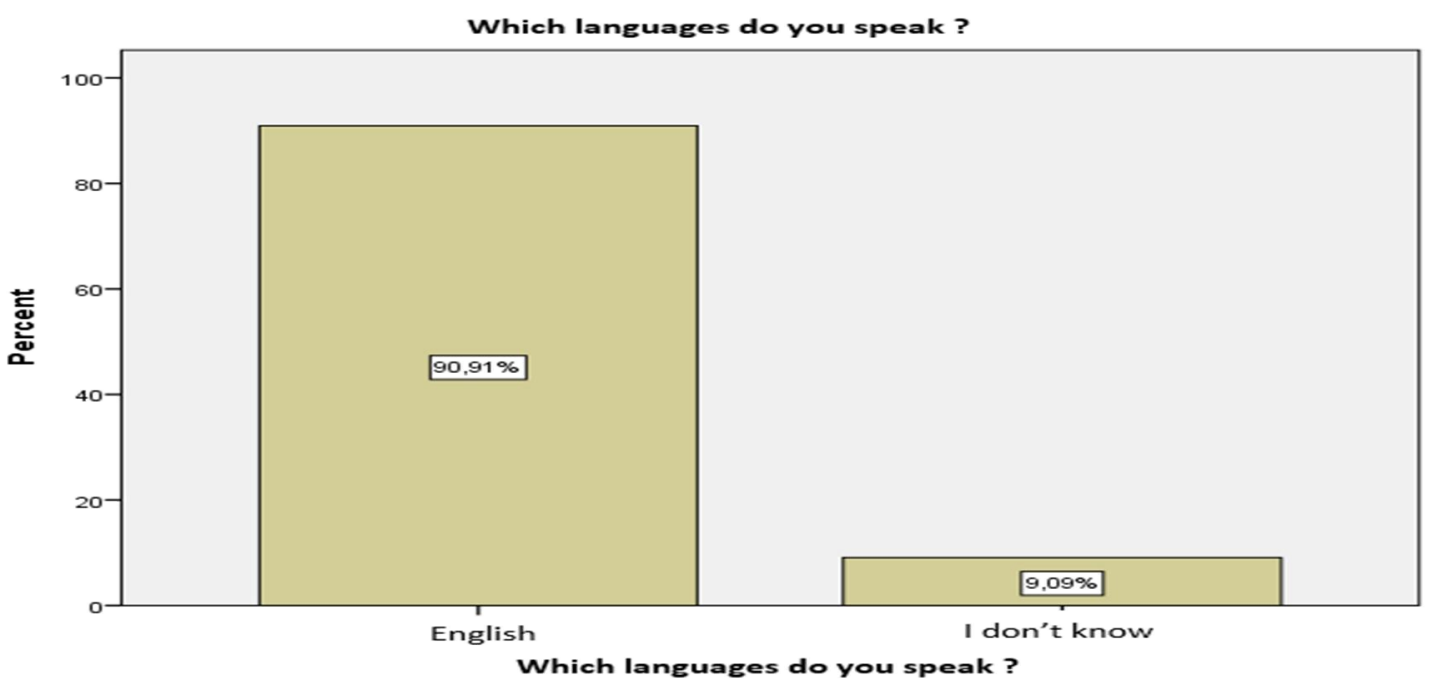

Figure 1: Foreign language knowledge of the doctors

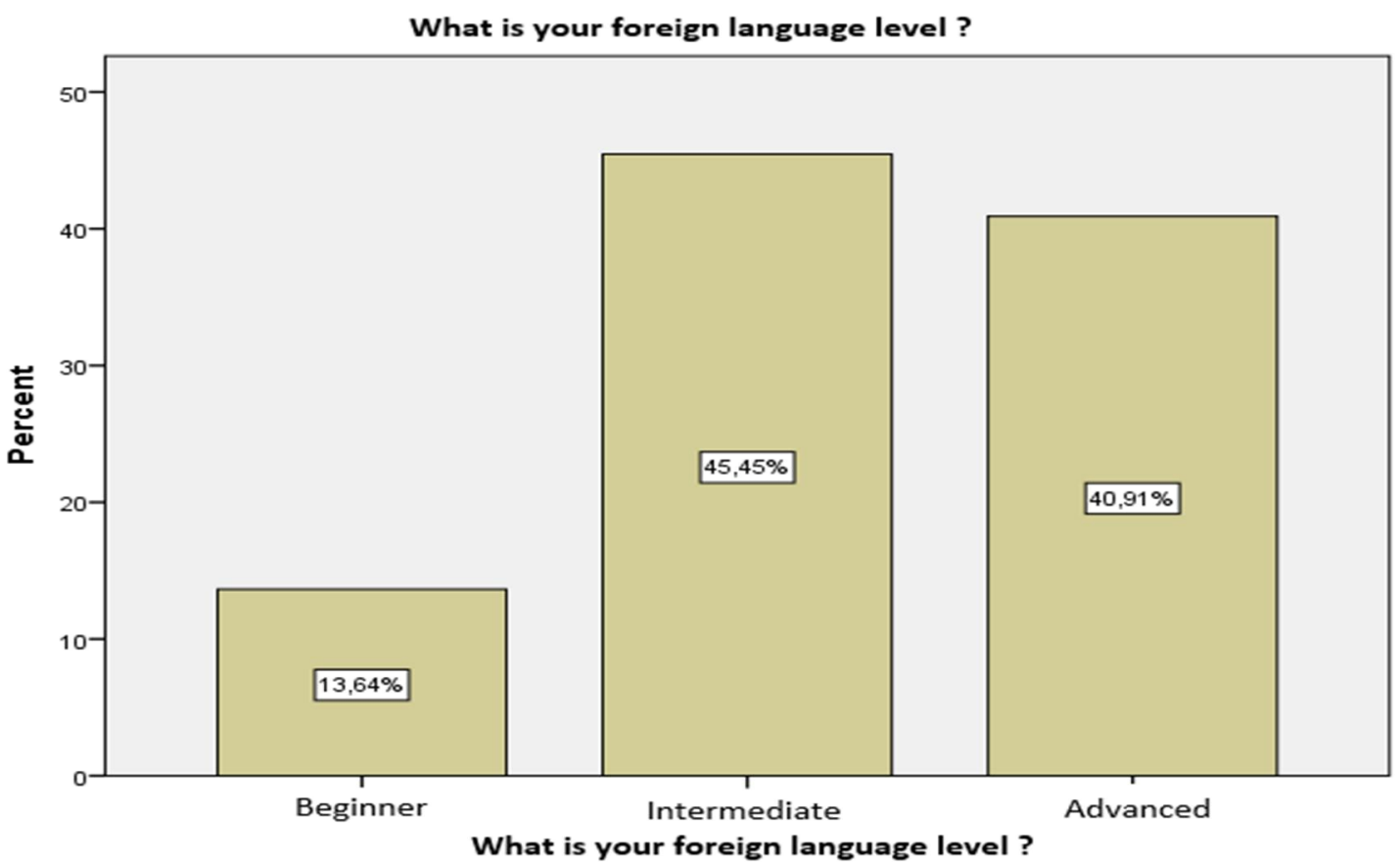

Figure 2: English level of doctors

As can be seen from Figure 2 above, 40,91\% of the doctors indicated that they are advanced in English, while the majority $(45,45 \%)$ declared that they are intermediate. Thus, it reveals the fact that a larger group of doctors are in need of interpreters to communicate efficiently with their foreign patients.

\subsection{User's Perception of Role and Expectancy Norms}

Four questions in total were posed to the doctors to unearth their expectations and perceptions of the interpreter's role. In other words, the expectancy norms will be explored under the sub-sections of interpreter's role, tasks, user expectations, and status perceptions. The first question with regard to the

Kadıköy - ISTANBUL / TURKEY 34714

e-mail: editor@rumelide.com, 
A Comparative analysis of role perceptions and expectations of medical doctors and interpreters in healthcare settings / O. Şener Erkırtay, Ş. Kıncal (pp. 1100-1118)

issue of role was asked to describe the task(s) of the interpreters in healthcare settings and three options were provided: "The interpreter always interprets only what the participants (healthcare providers and patients) say exactly, without any additions or omissions", "The interpreter makes additions, omissions or explanations only when necessary", and the third option was "The interpreter makes explanations, additions or omissions freely in the doctor-patient interview".

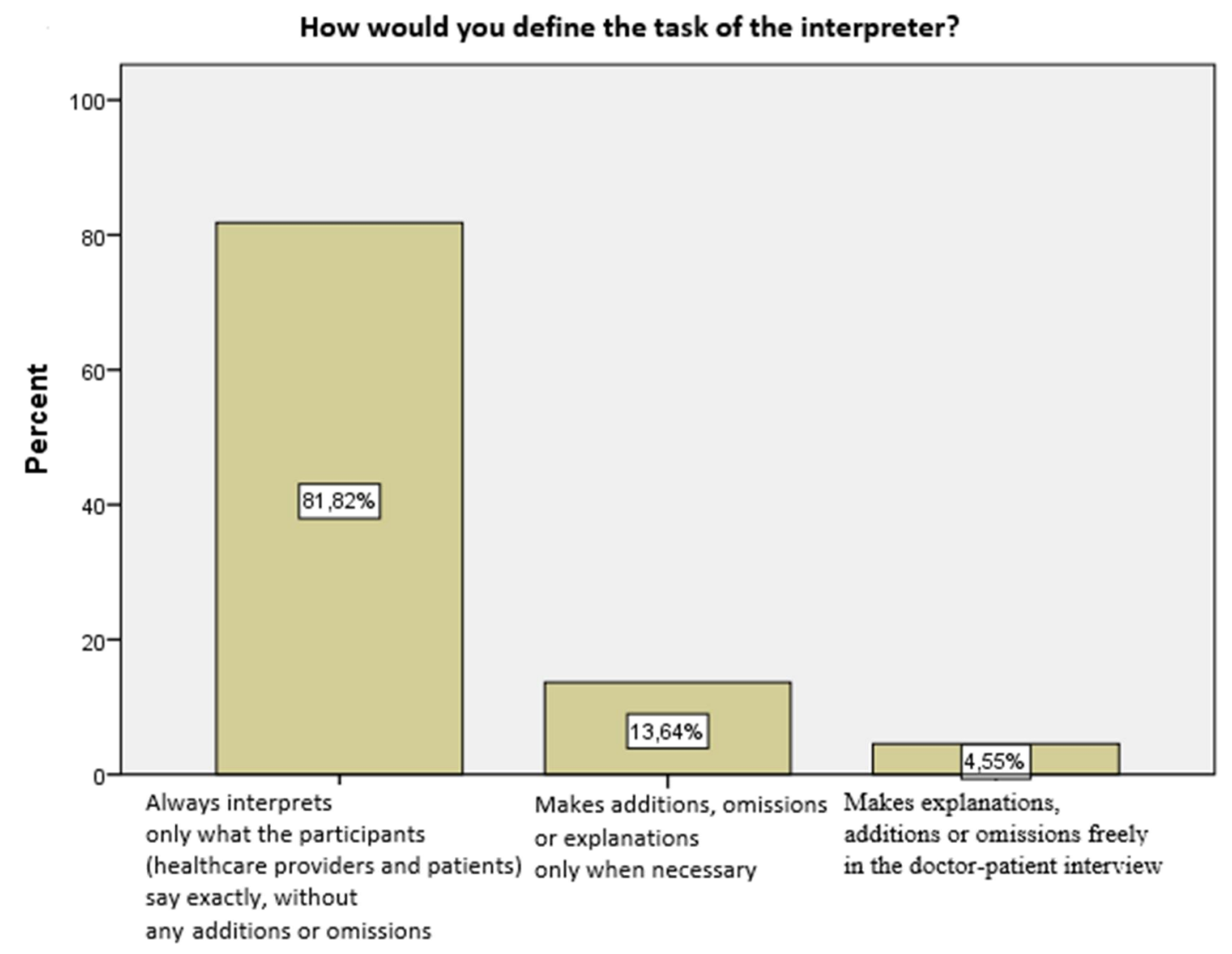

How would you define the task of the interpreter?

Figure 3: Doctors' descriptions of tasks of the interpreter

It becomes clear from Figure 3 that $81,82 \%$ of the doctors (18 out of 22 doctors) indicated that the interpreter should render only what the participants say, without any additions or omissions. This answer shows that the doctors perceive the interpreter as a neutral, uninvolved agent in the interaction. This result turns the interpreter into a "translation machine", which refers to literal, wordfor-word translations. So, it means that whereas the interpreter is expected to transfer only the words uttered by the doctor or patient, the task of making sense out of those utterings falls to the participants. However, it is also a fact that this kind of translation might lead to inaccurate translations because it overlooks the core message (Hale, 2007: 42).

To take this issue further, the role perceptions of the doctors were asked. These two questions are specifically valuable since they directly focus on the user's role perceptions of the interpreter as an active or neutral participant. The doctors were given two options: "The interpreter is an active agent, who is involved in the interaction, shapes and controls the communication between the participants" and "The interpreter is a neutral agent who merely interprets what the participants say and only

Adres $\mid$ Address

RumeliDE Dil ve Edebiyat Araştırmalar Dergisi $\quad$ RumeliDE Journal of Language and Literature Studies Osmanağa Mahallesi, Mürver Çiçeği Sokak, No:14/8 Osmanağa Mahallesi, Mürver Çiçeği Sokak, No:14/8

Kadıköy - İSTANBUL / TÜRKIYE 34714 Kadıköy - ISTANBUL / TURKEY 34714 e-posta: editor@rumelide.com e-mail: editor@rumelide.com,

tel: +90 505 7958124, +90 2167730616 phone: +90 505 7958124, +90 2167730616 
conveys the meaning of the words". Since this question and the previous one is directly linked to each other, the results obtained from this question is extra important to justify their previous answers.

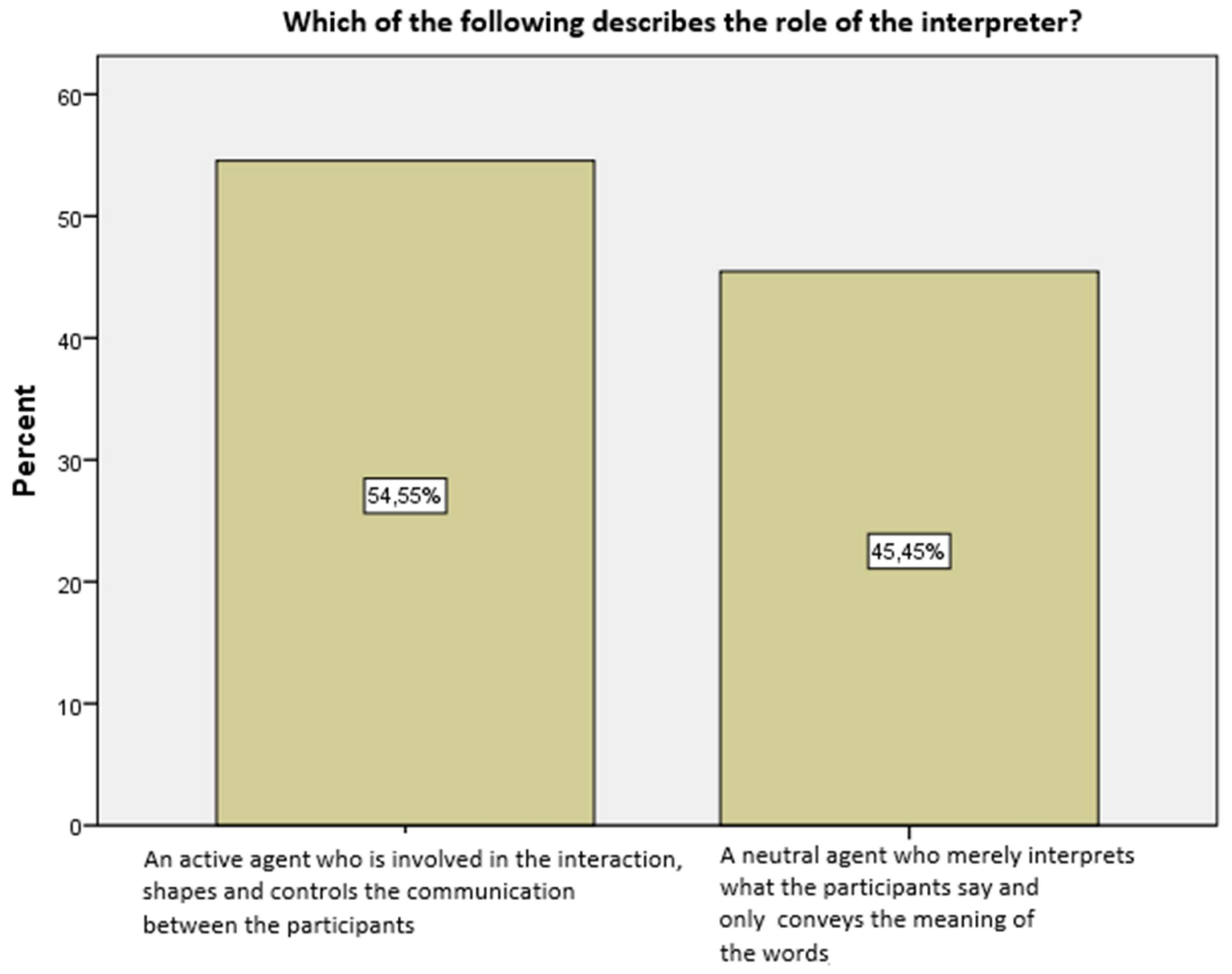

Which of the following describes the role of the interpreter?

Figure 4: Doctors' role perceptions of the interpreter

As can be deduced from Figure 4 above, there is a slight difference between the two ratings. While 12 doctors $(54,55 \%)$ argued that the interpreter is an active participant, the remaining 10 doctors $(45,45 \%)$ said the interpreter is a neutral agent. A larger group of doctors perceived the interpreter as an active participant. This result is remarkable since it contradicts with the previous answers in which the doctors clearly indicated that the interpreter is like a "translation machine" (see Figure 3).

Furthermore, when asked what the doctors expect from the interpreters in terms of tasks to be performed within the hospital, there were 2 options: "The interpreter should only interpret what the doctor/ hospital staff and patient say" and "The interpreter should also provide assistance in addition to the task of interpreting (patient's procedures, applications, tests, filling out forms, etc.). The first option refers to the "interpreter" role, while the other option entails various tasks apart from interpreting.

Address

RumeliDE Journal of Language and Literature Studies

Osmanağa Mahallesi, Mürver Çiçeği Sokak, No:14/8

Kadıköy - ISTANBUL / TURKEY 34714

e-mail: editor@rumelide.com,

phone: +90 5057958124 , +90 2167730616 
A Comparative analysis of role perceptions and expectations of medical doctors and interpreters in healthcare settings / O. Şener Erkırtay, Ş. Kıncal (pp. 1100-1118)

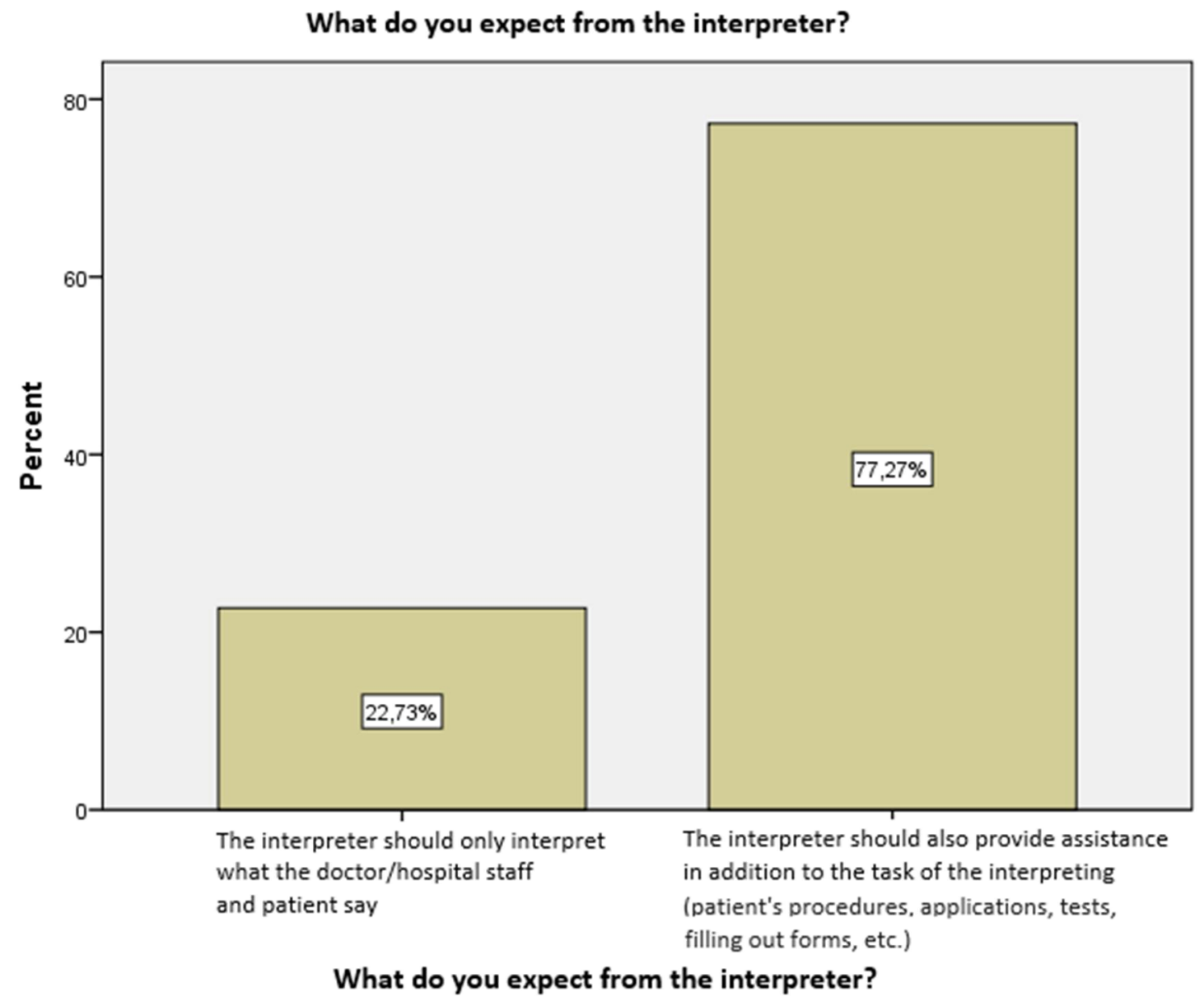

Figure 5: Doctors' expectations from the interpreters

It is revealed that the doctors primarily expect the interpreters to take on additional responsibilities in addition to the task of interpreting. In this regard, they expect the interpreters to go beyond their role as an "interpreter". Rather, it seems that the interpreters are expected to assume, for instance, the role of a "hospital attendant", "a guide", "a counsellor" etc. who deals with the patient's procedures within the hospital as if $\mathrm{s} /$ he were the patient's relative.

Lastly, the doctors were asked how they perceive the status of the healthcare interpreter within the hospital, which was almost the same with the other questions asked above. They were given 4 alternatives to choose: [The interpreter] "is an expert with his/her medical terminology knowledge", "a language expert (only as an interpreter)", "a hospital staff providing support for the hospital procedures", and "all of the above".

Address

RumeliDE Journal of Language and Literature Studies

Osmanağa Mahallesi, Mürver Çiçeği Sokak, No:14/8

Kadıköy - ISTANBUL / TURKEY 34714

e-mail: editor@rumelide.com,

phone: +90 5057958124 , +90 216773 o 616 


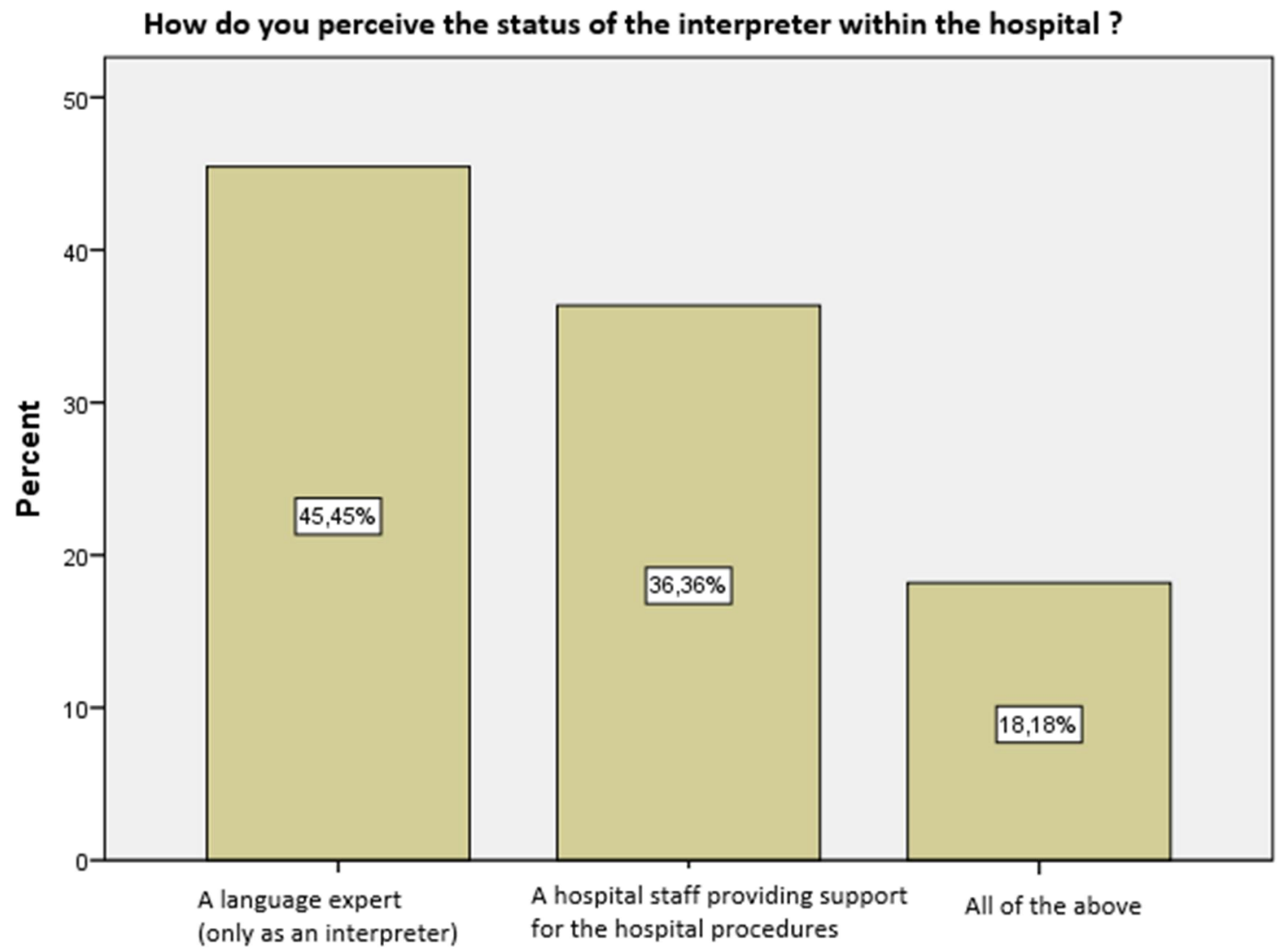

How do you perceive the status of the interpreter within the hospital ?

Figure 6: Doctors' status perception of the interpreters

When the answers given by the doctors are examined, it can be figured out that there is a slight difference between the first and the second option which is "a language expert" and "a hospital staff providing support for the hospital procedures". Despite this difference, more doctors tended to think of the interpreter only as a language expert. It is again astonishing that the doctors certainly declared that the interpreter should also be responsible for many other duties, which are beyond their capacities.

As a conclusion, it can be summed up that there were tricky questions so as to reveal real opinions of the users. Therefore, similar questions were directed to the doctors. However, some contradictory results came out of the analysis. First of all, when asked to describe the task(s) of the interpreter, a large number of doctors indicated that the interpreter is a neutral and uninvolved agent who merely transfers the messages like a "translation machine". However, when it comes to defining the interpreter's role, this time the doctors said that the interpreter is an active participant coordinating and shaping the interaction, which is in stark contrast to the previous answer. If the interpreter is expected to be an uninvolved agent, then s/he cannot be expected to get involved in the process and coordinate it. Likewise, most of the doctors also expect the interpreter to deal with a variety of tasks such as dealing with insurance claims of the patients, guiding the patients during the procedures, helping them to fill out forms, etc. All these tasks encumber the interpreter to additional roles such as the role of a hospital attendant, hospital staff, or even relative of the patient. Even yet, more doctors

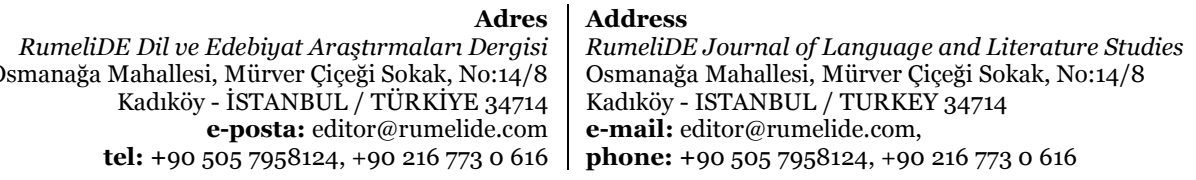


A Comparative analysis of role perceptions and expectations of medical doctors and interpreters in healthcare settings / O. Şener Erkırtay, Ş. Kıncal (pp. 1100-1118)

perceived the interpreter as a language expert. All these inconsistencies of the results clearly show the lack of awareness among the users regarding the role definitions and limitations of the interpreters.

\section{Analysis of the Interviews with Healthcare Interpreters}

To elicit data regarding the interpreter's self-perception of role and compare it with that of the users', open-ended semi-structured interviews were conducted with a total number of 13 healthcare interpreters working at private hospitals in Ankara, Istanbul, and Izmir during October 2020. There is a mix of genders, with 7 female interpreter and 6 male interpreters. Their ages are between 22 and 47 years. They have different language pairs. For example, 7 of them work in a single language pair between English and Turkish (4 interpreters), German and Turkish (2 interpreters) or French and Turkish (1 interpreter). There were also interpreters working between more than 2 or even 3 languages such as English-Turkish- German, Arabic- English-Turkish, English-French- Turkish or even between English-German-Dutch- Turkish. Except 3 interpreters, all interpreters graduated from Translation and Interpreting Department. As for their work experience in the field, it ranges from 3 months to 11 years.

To analyze and compare results obtained from the answers of the doctors and the interpreters, similar questions about 'role' were posed. Thus, the issue of 'role' will be discussed under the sub-headings: "interpreter's self-perception of role", "interpreter's self- perception of status within the hospital", and "interpreter's tasks and responsibilities besides interpreting". For confidentiality reasons, the interpreters were coded between INT1- INT13.

\subsection{Interpreter's Self-Perception of Role}

When the interpreters were asked to describe their role, they gave similar responses to those of the users. They defined their role as a "guide", a "counsellor", or a "representative" of the patient, providing both physical and psychological support.

EX1:

[I] think that I play an important role especially for the people who cannot speak foreign language because $I$ help them in fact during the whole process within the hospital or during the procedures. That is, I am, in fact, of the opinion that I play very important role for both parties who are doctors and patients. [INT13]

[[D]il bilmeyen yani hiç bilmeyen hastalarda özellikle bence çok büyük bir rol oynadığımı düşünüyorum çünkü yani hastaların eli, ayağı oluyorum aslında hastanede ya da o süreç boyunca. Yani her iki taraf için de doktor için de hasta için de çok önemli bir rol oynadığımı düşünüyorum açıç̧ası.]

INT13 strongly emphasizes the indispensable role he plays during the patient's treatment process not only for the patients but also for the doctors. A similar opinion was shared by INT1, who said:

\section{EX2:}

(Our role is) In the administrative division, let's say as a guide, as a manager ehmm, as a person who helps patients during their treatment process. [...] [INT1]

[İdari bölümünde, diyelim ki idari bir şekilde rehber gibi, idari gibi ehmm hastaların ehmm tedavi sürecinde destek olmak, yardımcı olmak. [...]]

\begin{tabular}{|c|c|}
\hline & \\
\hline aları $D$ & d Literatur \\
\hline $\mathrm{Mal}$ & Mahallesi, Mürver Çiçeği Sokak, No:14/8 \\
\hline Kadıköy & STANBUL / TURKEY 34714 \\
\hline $\begin{array}{r}\text { e-posta: edito } \\
\text { tel: }+905057958124,+\end{array}$ & $\begin{array}{l}\text { editor@rumelide.com, } \\
\text { +90 505 7958124, +90 } 216773 \text { o } 616\end{array}$ \\
\hline
\end{tabular}


As can be inferred from the statement above, the interpreter conceives his role not only as an interpreter, but also as a guide or a manager who coordinates and controls the whole process of the patient. Likewise, INT5 described his role as a "counsellor":

\section{EX3:}

As a healthcare interpreter, well that is: a person who accompanies the patient, I mean foreign patient, afterwards conduct paper works as if s/he were a counsellor for the patients. For the hospital I can say that I was like a mediator in order to manage insurance operations and of course to provide smooth communication with the patients. [INT5]

[Hastane çevirmeni olarak ehmm yani şöyle: hastalara, daha doğrusu yabancı hastalara eşlik eden, ardından da hani gerekli evrak işlerini yapan bir- hani hastalar için bir danışman diyebilirim bir nevi. Hastane için de bu sigorta süreçlerinin yürüyebilmesi, hastaların tabi ki daha rahat iletişim kurabilmeleri için bir aracı gibiydim diyebilirim.]

Just like INT13 and INT1, INT5 also shares a similar view on their role within the hospital and explained the scope of their tasks, which are not restricted to interpreting between the two languages. INT5 describes his role as a counsellor who accompanies the patient during the whole procedure, tracking the paperwork of the patients including insurance claims. He also expressed that he is perceived as a "mediator" by the hospital staff. At this point, INT1 broadens the descriptions of their role and takes the issue one step further by indicating that they also provide psychological support:

EX4:

From my perspective, interpreters do important things. For example, we strive to enable patients to receive an appropriate treatment, a correct medicine. Sometimes, how can I say? It is sometimes conducted as a psychological guidance. That is, when the illness of a patient is explained, (I say) "It is not important, it is not a serious illness", "I say 'disease' but it is curable disease, don't bother. Medical science has progressed". Let me give an example. We have patients awaiting a liver transplant. The patient comes (and asks) "Tell me, what happened?", "How will it be?", "Which procedure will be followed?". Then we explain. For example, I know that illness. Then I say "I have seen many patients transplanted. There is nothing to be afraid of". "You will be better". So, we provide something like psychological support. We advocate them as if we were a guide or a counsellor. [INT1]

[Benim bakış açısından tercümanlar çok önemli şeyler yapıyorlar. Mesela hastanın ehmm tedavi anlamında bir uğraş, doğru ilacı alması için, doğru tedaviyi alması için bir uğraş yapıyoruz. Bazen bir şey mesela nasıl diyeyim? Psikolojik rehberlik gibi de oluyor. İşte hastanın- hastaya bir hastalığı açıklandığı, yapıldığı zaman, şey yapıldığı zaman önemli bir ... "Yok işte önemli değil, çok ehmm büyük bir hastalık değil"- hastalık dediğim de "tedavisi mümkün”, "canını sıkma”, "bak işte tıp gelişti, tedavin mümkün olabilir". Mesela örnek vereyim size: karaciğer nakli hastalarımız oluyor işte. Geliyor hasta "Nasıl?”, “Anlatın bana, ne oldu?”, "Nasıl olacak?”, "Ne yapılacak?”. İşte anlatıyoruz ona. Mesela daha önceden gördüğüm hastalık. "Benim çok gördüğüm hastalar nakil oldular", "çok, yani o kadar da korkacak bir durum yok", "Daha iyi olacaksın”. Yani psikolojik bir destek gibi bir şey oluyoruz. Bir- rehberlik gibi, danışmanlık gibi, destek gibi oluyoruz.]

INT1 touches upon a striking point above expanding his role boundaries as a "guide". Furthermore, he also clarifies that he gives psychological support for the patient, when necessary. The same point is also highlighted by INT6:

\section{EX5:}

[N]ot all the staff dealing with patients can speak English. Thus, they need our help. Ehmm for example, they ask for help in positioning the patient or in turning the patient or when the patient is required not to move. They can communicate in some degree in those moments. However, for instance I need to talk about anesthesia before the procedure since it is a bit painful

RumeliDE Dil ve Edebiyat Araşttrmaları Dergisi Osmanağa Mahallesi, Mürver Çiçeği Sokak, No:14/8 Kadıköy - İSTANBUL / TÜRKIYY 34714 e-posta: editor@rumelide.com tel: +90 $5057958124,+902167730616$
Address

RumeliDE Journal of Language and Literature Studies

Osmanağa Mahallesi, Mürver Çiçeği Sokak, No:14/8

Kadıköy - ISTANBUL / TURKEY 34714

e-mail: editor@rumelide.com,

phone: +90 505 7958124, +90 2167730616 
A Comparative analysis of role perceptions and expectations of medical doctors and interpreters in healthcare settings / O. Şener Erkırtay, Ş. Kıncal (pp. 1100-1118)

process. The patient needs to be patient for ten minutes or so. Ehmm when all these are repeated every day, it is like automated. Apart from this, I was striving for having a talk with the patient and thus divert his/her attention away. [...] [INT6]

[[H]asta ile ilgilenen kişiler hepsi İngilizce bilmiyor. O kısımda size ihtiyaçları oluyor. Ehmm işte hastaya pozisyon verirken yardım istiyorlar genelde dönmesi gerektiği ya da kıpırdamaması gerektiği ile ilgili şeyde. Zaten artık yavaş yavaş öğrenmişler ama onun dışında işte işlemden önce mesela anestezi ỉle ilgili birazcık konuşmam gerekiyor çünkü birazcık acılı bir süreç o kısım. Bir 10 dakika falan dişini sıkması gerekiyor hastanın. Ehmm yani bunlar da zaten her gün her gün tekrarlanınca artık otomatiğe bağlandı gibi bir şey oldu. Onun dışında hastanın birazcık o süreçte dikkatini dağıtıp sohbet etmeye çalışıyordum. [...]]

As inferred from the statement above, INT6 emphasizes the importance of talking to the patient, especially when the patient is in pain. This comes more as an intuitive act of the interpreter instead of a task imposed on the interpreter. In such situations where the patient has trouble, the interpreters assert that they converse with the patient in order to relieve their pain by taking initiatives.

\subsection{Interpreter's Self-Perception of Status within the Hospital}

This part of the study relies on the interpreters' answers given to the question regarding the interpreter's prestige or status within the hospital. There were different approaches to the issue of status from the interpreter's perspectives. While a group of interpreters advocated that they are respected by the hospital staff, the other group claimed they do not get respect they deserve. For example, INT1 stated:

\section{EX6:}

In fact, they don't think the interpreters' profession as prestigious. They don't think that it is so important. They have an approach towards us as if we were a representative of the patient and say, "The interpreter deals with the patient's procedures". I can also give an example. For example, a wheelchair was needed, and you call and say, "The foreign patient needs wheelchair". They say "Well, why don't you send?". I am an interpreter there and I am not a bellboy. I don't despise bellboys here, but it is not my task there. Another example can be that they take the patient, for example. They say to me "Take the patient" or "Carry the patient's documents". There is not much respectability. [INT1]

[Aslında, açıça o kadar da bir şey ehmm bir prestij bir şey görmüyorlar. Çok önemli bir şey görmüyorlar. İşte hani dediğim gibi ilk başta geliyor hastanın bir temsilcisi gibi işte "hastanın işini halleder" falan felan. Mesela bazen bir örnek de vereyim: Hasta diyelim ki ehmm tekerlekli sandalye falan isteniyor, şey ediyor. Arıyorsun işte yabancı hasta işte "Aa, niye sen göndermiyorsun?" anlamında. Ben tercümanım burada, bellboy değilim ya da ... O, karşıdaki bellboy'u küçümseme anlamında değil ama o benim işim değil mesela. Ya da hastayı mesela bir yerden bir yere götürürken yatan hastayı götürüyorlar "sen götür" mesela ya da hastanın yanında giderken dosyası oluyor. "Sen taşı" mesela, falan filan. Bu anlamda işte biraz saygınlık yok sanki.]

In this case, INT1 complains about the additional tasks imposed on him, apart from the task of interpreting and considers such kind of tasks as devaluing them and ruining their status and prestige in the hospital. The same approach can be traced in the statements of INT5:

\section{EX7:}

I can say that the profession of interpreting doesn't receive a respect which it reserves. Because, if you don't deal with a patient at that moment, they can ask you "Can you also deal with this?". Or, if the executives need a translation, they can ask you "Can you translate this document?", even if it is not among your responsibilities. Therefore, I think that it doesn't receive a respect deserved. Yet, I also don't think that we are otherized in the hospital. However, I don't think that we receive respect that we deserve. Especially in financial terms, when we take our salaries into account. [INT5]

\footnotetext{
RumeliDE Dil ve Edebiyat Arașttrmalar Dergisi Osmanağa Mahallesi, Mürver Ciçeği Sokak, No:14/8 Kadıköy - İSTANBUL / TÜRKIYE 34714 e-posta: editor@rumelide.com tel: +90 505 7958124, +90 2167730616

Address

RumeliDE Journal of Language and Literature Studies Osmanağa Mahallesi, Mürver Çiçeği Sokak, No:14/8

Kadıköy - ISTANBUL / TURKEY 34714

e-mail: editor@rumelide.com,

phone: +90 5057958124 , +90 2167730616
} 
[Yani çok hak ettiği yeri görmediğini söyleyebilirim açıç̧ası. Ehmm çünkü hani eğer mesela hasta yoksa, gerekirse hani böyle işte "şu işi de yapar mısın?" falan hani böyle ya da yöneticilerin bir çeviriye ihtiyacı varsa, hiç senin görev tanımında olmasa bile hani sana gönderip, "Bunu da çevirir misin?” falan gibi böyle iş kakalama gibi. Ehmm şey de vardı açıkçası. Hani- o yüzden çok görevine, mesleğine saygı- yani çok fazla, olması gerektiği kadar olduğunu düşünmüyorum. Ama yine de çok ötelendiğimizi düşünmüyorum hastanede ama. Ehmm ama yine de hak ettiğimiz değeri gördüğümüzü düşünmüyorum açıkçası. Özellikle de maddi yönde hani. Aldığımız maaş bazında düşününce.]

Like INT1, INT5 also thought that their profession is undermined and for that reason the hospital staff expect them to take on unrelated tasks, which are not acceptable by the interpreters. Moreover, INT10 introduced a new aspect into the discussion, focusing on the financial side of the profession and gave a remarkable example:

\section{EX8:}

If we conceive interpreters only as interpreters- I mean, if we consider interpreters' prestige only as interpreters, then I can say that it is not very prestigious. You aren't appreciated only as an interpreter from the users' perspective. Having additional titles apart from being just an interpreter and taking additional responsibilities will increase your reputation. Right in the beginning, your position is already very important. If you are employed only as an interpreter, then people don't understand your value. They don't know how important it is because there aren't much people who are received language education. There aren't many experts in language. You interpret for the people who haven't received that education, but it is your job as an interpreter. However, the role of interpreters isn't much respected in our country. Particularly the hospital is a trade place. I was working at a private hospital. As I said, the time is money here. Everything comes from money. In such a place, the interpreter isn't considered important because $s / h e$ is only in the role of an interpreter, not in the role of a person who brings money to the hospital. S/he only provides service. Therefore, s/he doesn't' receive the reputation that s/he deserves. At least, the hospital executives have this opinion. [INT10]

[Sadece hastane çevirmeni olarak bakarsak yani sadece çevirmen olarak bakarsak çok iyi görmüyorum maalesef. Ehmm yani sadece çeviri yapmak insanların gözünde çok fazla değer arz etmiyor maalesef. Onun yerinde farklı title'lara sahip olmak, farklı sorumluluklar almak sizin saygınlığınızı artıracaktır. Zaten pozisyona girdiğiniz zaman ne pozisyonda girdiğiniz çok önemli ama çevirmen olarak- sadece çevirmen olarak girdiğiniz zaman maalesef insanlar bunun değerini anlayamıyorlar. Ne kadar önemli bir iş olduğunu bilemiyorlar çünkü dil eğitimi alan çok fazla insan yok. Dil konusunda uzman olan çok fazla insan yok. Siz zaten uzman olmayan insanlara yapıyorsunuz ki çevirmen olarak rolünüz de bu ama maalesef ülkemizde çevirmen rolü çok fazla değer arz eden bir rol değil. Özellikle de hastane- ya da şöyle söyleyeyim: ticaret yapılan yerlerdeçünkü aslında hastane de bir ticaret yapılan bir yer- ben özel hastanede çalışıyordum. Burada dediğim gibi vakit nakittir. Her şey paradan dönüyor. Öyle bir yer olduğu zaman çevirmen maalesef çok önemli sayılmıyor çünkü çevirmen tek sadece çevirmen rolünde olduğu zaman aslında parayı getiren rol değil, sadece hizmet rolünde oluyor. O yüzden yeterli değere sahip olmuyor. Yani en azından patronun gözünde o şekilde.]

INT10 places an emphasis on the financial aspect of their profession and claims that only when the interpreters contribute to the hospital in financial terms, in other words, if they make the hospital earn money, then they receive reputation in the hospital. According to the statement above, providing communication between the participants is not enough for the hospital and financial interests have more importance.

When all the answers handled above are taken into account, it can be suggested that the interpreters have various approaches, some of whom declared that their profession is well respected. On the other hand, there are interpreters who are not content with their status because of the irrelevant tasks imposed on them. It becomes obvious that those tasks make the interpreters feel insignificant, even though the interpreters play a determining role in bridging the gap between the parties. Thus, it might

Adres

RumeliDE Dil ve Edebiyat Araşttrmaları Dergisi Osmanağa Mahallesi, Mürver Çiçeği Sokak, No:14/8 Kadıköy - ÍSTANBUL / TÜRKIYE 34714 e-posta: editor@rumelide.com tel: +90 505 7958124, +90 2167730616
Address

RumeliDE Journal of Language and Literature Studies

Osmanağa Mahallesi, Mürver Çiçeği Sokak, No:14/8

Kadıköy - ISTANBUL / TURKEY 34714

e-mail: editor@rumelide.com,

phone: +90 5057958124 , +90 2167730616 
A Comparative analysis of role perceptions and expectations of medical doctors and interpreters in healthcare settings / O. Şener Erkırtay, Ş. Kıncal (pp. 1100-1118)

also lead to a lack of motivation among the interpreters which might have negative effect on their performances as well.

\subsection{Tasks and Responsibilities besides Interpreting}

The last part on the issue of role includes the discussions about additional tasks the interpreters deal with. Thus, the interpreters were asked whether they undertake other responsibilities other than interpreting. All interpreters, except one, admitted that they are also responsible for many other duties. INT9 lists those tasks extensively:

\section{EX9:}

[...] Registration of the patients, if the fee isn't received correctly, calling the fee center, reaching the person representing the patient's country, finding the correct price by negotiating with her/him, giving a regional discount, if there is any, a lot of thing like this. I also help the patient's pharmaceutist to communicate, because the pharmaceutist cannot speak foreign language. The hospital doesn't provide service for this. International hospital might be providing such services, but I haven't encountered. Also, the transfer of the patient. Dealing with return transfer of the patient by getting in contact with the related person. There are a lot of extra duties. It is not limited to interpreting. [INT9]

[[...] Hastanın sürekli- girişinden kayıtın- kayıtı, ücret alınması ehmm doğru alınmadıysa ücret merkezi aramak, merkezde onun temsilcisi olduğu ülkenin ehmm ülkesini temsil eden kişiye ulaşmak. Onunla tekrar müzakere edip doğru fiyatı bulmak, bölge indirimi varsa onu yapmak, ehmm bunun gibi birçok şey. Bazen eczanesine tabi öyle şeylere de yardım ettiğim çok oluyor. Eczane bilmiyor çünkü. Hastanenin böyle bir servisi yok. Ehmm uluslararasında vardır hani sabit şeylerde belki vardır ama ehmm benim karşlaștığım birçok alanda- sonra transferi. Dönüş transferini ilgili kişiye iletip transferini sağlamak. Birçok ekstra şeyleri de oluyor. Sadece tercüme değil.]

As one can infer from the passage above, the interpreter's task is not restricted to transferring messages between the parties during the encounters. After the encounters, the interpreter's tasks continue, and $\mathrm{s} / \mathrm{he}$ is the one who is responsible for solving the problems, if any. INT9 exemplifies at this point the costs of the patient's procedures. It falls to the interpreter to negotiate with the insurance company of the patient and find the correct price, if there is a mistake with the prices. The statements of INT9 actually exemplifies the statements of INT10 above, who highlighted the interpreter's important role even in financial terms. Apart from that, the interpreter is understood to provide assistance in other situations as well, for example, in providing medicine for the patient. Likewise, the transfer of the patients also takes place under the coordination of the interpreters.

INT7 and INT10 mentioned that they have additional responsibilities under different titles other than the "interpreter". INT7 said that she is working at the department of "sales marketing":

\section{EX10:}

[I]n fact I am working at the department of "sales marketing". Interpreting constitutes only a part of my job. I think this case is all the same in most hospitals. There are not many hospitals and departments in Izmir, but the case is the same in most hospitals because the target receiver is health tourism patients. Therefore, my main responsibility is regarding sales marketing, which includes getting in contact with the patient, listening to their requests and afterwards offering them price, responding, informing, helping them while purchasing flight ticket We also arrange their appointments by informing them regarding which airport they should come on which dates. We arrange their appointments and hotels. We also deal with their transfers between the airport, hotel and the hospital. The patients get in contact only with us from the hospital before coming to Turkey. After returning their countries, we also get in contact with them. If they need to ask something to a

RumeliDE Dil ve Edebiyat Araștırmaları Dergisi Osmanağa Mahallesi, Mürver Ciçeği Sokak, No:14/8 Kadıköy - ISTANBUL / TÜRKIYE 34714 e-posta: editor@rumelide.com tel: +90 505 7958124, +90 2167730616
Address

RumeliDE Journal of Language and Literature Studies

Osmanağa Mahallesi, Mürver Çiçeği Sokak, No:14/8

Kadıköy - ISTANBUL / TURKEY 34714

e-mail: editor@rumelide.com,

phone: +90 5057958124 , +90 2167730616 
doctor, they pose their questions to us. We ask to the doctor and then inform them. We are also involved in the "post-op" process, after they return to their countries after their operation. [INT7]

\begin{abstract}
[[S]atıș pazarlama bölümüindeyim aslında. Tercümanlık dediğim gibi işin sadece bir kısmı. Bu zaten sanıyorum çoğu hastanede de bu şekildedir. İzmir'de çok fazla hastanede yok gerçi böyle departmanlar ama çoğu hastanede bu şekilde oluyor çünkü erek kitle sağllk turizmi hastası ehmm bunun - yani bu nedenle üstlendiğim görevler öncelikle satış pazarlama kısmı. Yani hastayla ilk olarak diyaloğa geçme, hastanın isteklerini dinleme, sonrasında ona bir fiyat teklifi sunma, yanıt verme, bilgilendirme sağlama, uçak biletleri bakarken ona destek olma, hangi- işte hava alanından alması gerektiğini, hangi tarihleri alacağını randevusunu ayarlıyoruz. Otellerini biz ayarlıyoruz. Bunun dışından havalimanı hastane ve kalacağı adres arasında transferlerini biz yapıyoruz. Hastaya gelmeden önce hastanın tek muhatap kişisi biziz hastaneden, gittikten sonra da yine aynı şekilde doktora bir şey danışması gerekiyorsa bize soruyor. Biz doktora sorup hastaya söylüyoruz. Yani "post-op" dediğimiz ameliyat sonrası hasta ülkesine döndükten sonra takibinde de yer alıyoruz.]
\end{abstract}

INT7 expressed that the task of interpreting constitutes only a small part of her tasks. She assumes a variety of tasks pertaining to the sales and marketing department, which has no direct relation with the task of interpreting. The answer above also reveals the fact that the interpreter assumes a role of hospital attendant by guiding the patient through all the procedures. Additionally, conducting a market research about the patients, informing them about the prices, organizing the patient's flights, and providing guidance through all the procedures are within the scope of the interpreter's responsibility. Likewise, INT10 remarked that he was employed as an "operation specialist".

\title{
EX11:
}

[...] I was employed as an operation specialist. [...] I have actually a number of responsibilities under the title "operation specialist". Let me explain: There has been a health tourism trend abroad in recent years. Some processes need to be managed here. I was managing this process. I was a mediator. So, what is it? Making agreements with agencies, agency research, market research, making agreements with hotels, organizing transfers, marketing, preparing advertisements, making statements there, posts in the website, etc. All these are included in my job. [...] Interpreting, in fact, constitutes a large part of all my responsibilities because all are related to language. You conduct all these responsibilities with your language competence. Thus, interpreting is also included in this process. For example, when you write a text for advertisement, you also translate it or when you write an informative text in the website, for instance, I was writing these texts on the website and they needed to be translated into three languages. Thus, you upload them to the website. You give them to graphic designer. S/he arranges texts and uploads to the website. Actually, texts belong to you. You both create them and translate them. [INT10]

[[...] operasyon uzmanı olarak işe alındım. [...] Operasyon uzmanı olarak aslında birçok görevimiz var. Mesela şöyle anlatayım: yurt dışında biliyorsunuz son yıllarda bir sağlık turizmi trendi var. Burada bazı süreçlerin yönetilmesi gerekiyor. Ben bu süreç yönetimini yapan kişiydim. Buradaki ara bulucuydum yani. Nedir bu? Acentalarla olan anlaşmalar, acenta araştırması, piyasa araştırması, otellerle yapılan anlaşmalar, transferlerin ayarlanması, onun dışında satış kısmı, pazarlama, reklamların hazırlanması, oradaki demeçlerin verilmesi, sitelerdeki yazılar vs. bunların hepsi var içinde. [...] Çeviri aslında bunun büyük bir kısmını oluşturuyor çünkü tamamen dille bağdaşık bir süreç. Ehmm yani dilinizi kullanarak yapıyorsunuz. O yüzden çeviri bu işin içinde var. Mesela siz reklam için bir metin yazdığınız zaman onun çevirisini de kendiniz yapıyorsunuz ya da sitede bir bilgilendirme yazısı yazdığınız zaman, sitedeki yazıları atıyorum ben yazıyordum, onların yine üç dile çevrilmesi gerekiyor. E siz yüklüyorsunuz siteye yani. Onları yazıyorsunuz düz bir metin olarak. Grafikere veriyorsunuz. O kendisi ayarlayıp siteye yüklüyor ama yazdığımız şey aslında sizin yazınız, hem de sizin çeviriniz aynı zamanda.]

INT10 gave a very similar response to that of INT7 and explained that he is conducting a market research, organizing transfers of the patients, making agreements with the health tourism companies, preparing advertisements of the hospital and translating them. In other words, he is also liable for finding patients to the hospital. All these remarks of INT 7 and INT10 verify the claims asserted above regarding the fact that only when interpreters bring money to the hospital, then they are regarded as 
A Comparative analysis of role perceptions and expectations of medical doctors and interpreters in healthcare settings / O. Şener Erkırtay, Ş. Kıncal (pp. 1100-1118)

prestigious. All these financial tasks and responsibilities taken on by the interpreter also underlined the indispensable role the interpreter plays.

\section{Discussion of the Findings}

The opinions of the doctors and the interpreters were discussed comparatively in accordance with the expectancy norms and the professional norms. First and foremost, it became obvious that the answers of the doctors entailed inconsistencies within itself. For instance, they, on the one hand, indicated that the interpreter is a neutral agent who only transfers the utterances of the parties without any additions or omissions, just like a "translation machine". On the other hand, they described the interpreter as an active participant who coordinates and shapes the interaction. Both alternatives cannot be valid at the same time, since the two options conflict with each other. The reason might be that the doctors chose the ideal option which is a "neutral", "uninvolved" interpreter perception. However, they even furthered their perception of an active interpreter by expecting them to deal with a number of tasks such as filling out forms, guiding the patients, etc., which lead the interpreter to assume various roles besides just being an "interpreter". These inconsistencies clearly show the gap between how the doctors image the interpreters in their minds and what they expect the interpreter to do in real life. From the interpreters' perspective, they displayed that they meet the user's expectations by dealing with a variety of tasks, in theoretical terms, expectancy norms determined by the users. What is interesting at this point is that the answers of the interpreters also revealed a gap between the role perceptions of the doctors and the interpreters. The answers of the doctors seem to reflect the idea that the interpreter comes forward as someone who could undertake all the responsibilities regardless of being related to the task of interpreting or not. This role gap could also be traced in the answers of the interpreters in that they feel their profession is not accepted as prestigious, thus they are imposed on unrelated tasks. Some of the interpreters further asserted that they were recruited under different titles and responsibilities instead of being an 'interpreter'. However, the interpreters depicted their role more as "facilitator" and/or "advocator" for both parties. One of its strongest evidence is that they stated they also provide psychological support for the patients, which comes as an intuitive act. At the other end of the spectrum, they advocate the hospital interests including their financial interests. All these point to the reinforcing of awareness regarding the complex role of healthcare interpreters among the users.

\section{Conclusion}

This study attempts to provide an in-depth comparative analysis of role perceptions of doctors and healthcare interpreters. The user's expectations and perceptions are among the significant factors having an impact on the role of the interpreter. Therefore, it is significant to reveal the user's role perceptions and expectations. With this purpose, 22 medical doctors working in private hospitals in Turkey filled out questionnaires and interviews were conducted with 13 interpreters.

The answers of both the doctors and the interpreters proved the fact that the interpreters play an instrumental role not only during the interactions, but also before and even after the doctor- patient encounters. However, we can come to a conclusion that the role gap is twofold. First, the inconsistencies were detected in the doctors' answers, which also direct us to the conclusion of a lack of awareness among them. Because, even though they describe the interpreter as a translation machine or perceive them only as a language expert, they expect more than that in real life conditions, which might from time to time go beyond the task of interpreting. Second, there seems to be a role gap

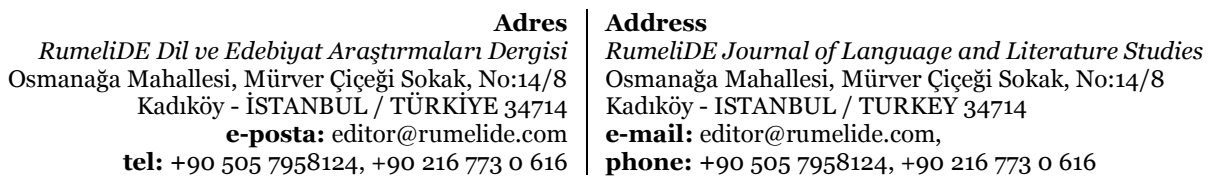


between the role perceptions of the doctors and the interpreters. Even though the doctors seem to perceive the interpreter as someone who deals with all types of tasks, including even the unrelated tasks, the interpreters seem to perceive themselves as "facilitators" and "advocators" for the parties.

All in all, as suggested by the questionnaires given to the doctors and the interviews conducted with the interpreters, discrepancies occur between the way the interpreter's role is perceived and defined, and the way interpreters are expected to behave in various situations. These discrepancies will be further analyzed in terms of the perspectives of the other users involved in the interactions and observations of actual practice within the scope of the ongoing broader study.

\section{Acknowledgements}

We would like to thank to all medical doctors and interpreters, who collaborated and contributed to the study by allocating their valuable time and sharing their experience with us. We would also like to express our special thanks to the co-supervisor of this ongoing PhD research, Prof. Dr. Ebru Diriker, for her valuable comments and suggestions for the research.

\section{References}

Aslanova, K. (2013). Türkiye'de Sağlık Turizmi ve Sağlık Turizmi Hukuku. (pp. 129- 145). Avrasya Uluslararası Araştırmalar Dergisi. 2:3

Balc1- Tison, A. (2016). The Interpreter's Involvement in a Translated Institution. A Case Study of Sermon Interpreting. Unpublished Doctoral Thesis. Rovira I Virgili University

Bolden, G. B. (2000). Toward understanding practices of medical interpreting: Interpreters' involvement in history taking. Discourse Studies, 2, 387-419.

Chesterman, A. (1997). Memes of Translation. Amsterdam and Philadelphia: John Benjamins

Diriker, E. (2004). De/Re-Contextualizing Conference Interpreting: Interpreters in the Ivory Tower. John Benjamins Publishing Company: Amsterdam/ Philadelphia

Duman, D. (2018). Toplum Çevirmenliğine Yorumbilimsel Bir Yaklaşım: Sağllk Çevirmeni ve Öznellik (A Hermeneutic Approach to Community Interpreting: Healthcare Interpreter and Subjectivity) (Doctoral Dissertation). Ylldız Teknik University: Istanbul.

Garzone, G. (2015). "Norms". In Routledge Encyclopedia of Interpreting Studies (Edited by Franz Pöchhacker). pp: 281- 283. London: Routledge

Gile, D. (1999). "Norms in Research on Conference Interpreting: A Response to Theo Hermans and Gideon Toury" in Translation and Norms. Current Issues in Language and Society (Ed. by Schaefnerr, C.) (pp. 99- 107). Clevedon: Multilingual matters.

Güven, M. (2014). Distance Learning as an Effective Tool for Medical Interpreting Training in Turkey. (pp. 116-130). Open Learning. The Journal of Open, Distance and eLearning. 29:2

Hale, S. (2007). Community Interpreting. New York: Palgrave Macmillan.

Hale, S. and Napier, J. (2013). Research Methods in Interpreting: A Practical Research. London: Bloomsbury

Harris, B. (1990). "Norms in Interpretation". (pp. 115- 119). Target (2):1, John Benjamins Publishing Company: Amsterdam/ Philadelphia

Katar, B. (2019). Dolmetschen im Medizinischen Bereich. Eine Fallstudie zu Aufgaben- und Rollenprofile von Dolmetscherinnen in der Türkei. (Unpublished Master's Thesis). Ege University, Izmir

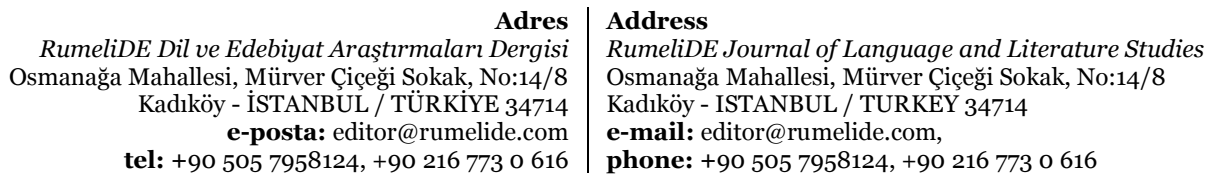


A Comparative analysis of role perceptions and expectations of medical doctors and interpreters in healthcare settings / O. Şener Erkırtay, Ş. Kıncal (pp. 1100-1118)

Koscialkowska-Okonska, E. (2011). "The concept of Norm in Professional (Legal) Translation and Interpreting: The Trainee (User) View”. Comparative Legilinguistics. 5/2011. (pp. 23- 33).

Özkaya, E. (2015). Konferans Çevirmenliğinde Normlar Işı̆̆ında Tarafsızlık Kavramı. Unpublished Doctoral Thesis. Istanbul University: Istanbul

Özsöz, B. (2019). Toplum Çevirmenliği Bağlamında Sağllk Turizmindeki Diyalog Çevirilerine Dilbilimsel ve Çeviribilimsel Yaklaşum (A Linguistic and Translation Research Oriented Approach To Interpreter Mediated Dialogues In Medical Tourism) Unpublished Doctoral Dissertation. Sakarya University: Sakarya

Öztürk, T. (2015). Küresel Hareketlilik Etkisinde Türkiye'de Sağllk Çevirmenliği Uygulamaları: Çevirmen Görüşlerine Dayal Bir Çalışma. Unpublished MA Thesis. Sakarya University: Sakarya

Ross, J. and Dereboy, I. (2009). Ad-hoc interpreters in medical settings in eastern and southeastern Anatolia: Findings of a recent study. Unpublished manuscript

Saldanha, G. and O'Brien, S. (2013). Research Methodologies in Translation Studies. London and New York: Routledge.

Shlesinger, M. (1989). "Extending the theory of translation to interpretation: norms as a case in point". Target 1(2): 111-115.

Şan, F. \& Kahraman Duru, R. (2020). COVID-19 koşullarında sağllk çevirmenliği hizmetleri ve toplum çevirmenliğinde "Yeni Normal”'i düşünmek. RumeliDE Dil ve Edebiyat Araştırmaları Dergisi. 2020.20 (Eylül). 816- 843.

Şener, O. (2017). Healthcare interpreting in Turkey: Role and ethics from a sociological perspective. (Unpublished MA thesis). Dokuz Eylül University: Izmir

Toker, S. S. (2019). Evaluation of Adaptation Training Provided by The Ministry of Health and The World Health Organization: Patient Guides Within the Context of Healthcare Interpreting Training in Turkey. (Unpublished Master's Thesis). Hacettepe University: Ankara

Toury, G. (1995). Descriptive Translation Studies and Beyond. Amsterdam and Philadelphia: John Benjamins

Turan, D. (2016). Sağ lık Hizmetlerinde Sözlü Çeviri Hizmetleri. Grafiker Yayınevi.

Van De Mieeroop, D. (2012). The quotative 'he/she says' in interpreted doctor- patient interaction. Interpreting. 14(1): 92- 117.

Wadensjö, C. (1998). Interpreting as Interaction. London and New York: Longman

\footnotetext{
Adres $\mid$ Address

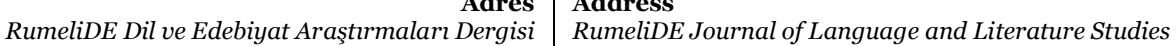
Osmanağa Mahallesi, Mürver Çiçeği Sokak, No:14/8 Osmanağa Mahallesi, Mürver Çiçeği Sokak, No:14/8 Kadıköy - İSTANBUL / TÜRKIYE 34714 Kadıköy - ISTANBUL / TURKEY 34714 e-posta: editor@rumelide.com e-mail: editor@rumelide.com,

tel: +90 505 7958124, +90 2167730616 phone: +90 505 7958124, +90 2167730616
} 